\title{
The relationship between psychological capital, organisational commitment and job satisfaction in the fisheries sector - A case study of fisheries sub-department of Thai Binh Province
}

\author{
Nguyen Danh Nam ${ }^{1 *}$, Uong Thi Ngoc Lan ${ }^{2}$ \\ ${ }^{1}$ Hanoi University of Natural Resources and Environment, Vietnam \\ ${ }^{2}$ Independent Researcher, Vietnam \\ *Corresponding author: ndnam.dr.90@gmail.com
}

\begin{abstract}
ARTICLE INFO
ABSTRACT

DOI: $10.46223 / \mathrm{HCMCOUJS.}$ econ.en.12.1.2013.2022

Received: July $26^{\text {th }}, 2021$

Revised: September $24^{\text {th }}, 2021$

Accepted: October $10^{\text {th }}, 2021$

Keywords:

job satisfaction; organisational commitment; psychological capital

The study is done to analyse the serious relationship between psychological capital, organisational commitment, and job satisfaction in the fisheries sector, a case study of Fisheries SubDepartment of Thai Binh Province. The empirical data collects through 237 questionnaires surveyed by civil servants working at the Fisheries Sub-Department of Thai Binh Province. The study applies exploratory factor analysis, confirmatory factor analysis, structural equation modeling to evaluate the relationship between psychological capital, organisational commitment, and job satisfaction of civil servants. The analysis results show a direct impact of psychological capital on organisational commitment, and psychological capital has an indirect effect on job satisfaction. The results also show a correlation between organisational commitment and job satisfaction. The study suggested significant policy implications for the Fisheries Sub-Department of Thai Binh Province to increase organisational commitment and job satisfaction.
\end{abstract}

\section{Introduction}

Over the past decade, Vietnam has undergone an important economic, social and organisational change. Due to the fast transformation of a market economy, public organisations and private sectors face complex and ever-changing competitive environments. Therefore, leaders and members of the organisation must be adapted to the rapidly changing work environment to pursue sustainable development (Spreitzer \& Porath, 2012).

Hence, maintaining high-quality human resources is imperative during this period. However, maintaining human resources requires the organisation to meet the needs of employees, and it is recognized through employee job satisfaction (Youssef \& Luthans, 2007). The studies of Nguyen (2015), $\mathrm{Vu}$ and Nguyen (2018) focus on studying the component factors affecting job satisfaction, therefrom achieving commitment. These studies focus on studying the impact of factors such as salary, benefits, leadership, colleagues on job satisfaction and organisational commitment. There are very few studies that discuss the psychological capital effect on organisational commitment and job satisfaction. 
Psychological capital is a relatively new field in the study on job satisfaction and organisational commitment, such as the study of Carver, Lehman, and Antoni (2003), Meng, Qi, and Li (2011), Mirkamali and Narenji (2011). Karatepe and Karadas (2015) argue that psychological capital and job engagement will promote employee satisfaction in the organisation.

Thai Binh Province has a coastline of 54 kilometers, with many potentials and strengths to develop the fishery economy. According to Fisheries Sub-Department of Thai Binh Province (2020), the total fishery output reached more than 260 thousand tons; increased by $6.53 \%$ compared to 2019, revenue reached 5,300billion VND, contributing 6\% of GDP. Thus, a fishery is a key economic sector of Thai Binh Province. The Fisheries Sub-Department of Thai Binh Province plays an important role in making plans and orientations for people in developing the province's fishery economy. With the outbreak of the Covid-19 pandemic, the economic situation is facing difficulties and challenges. The Fisheries Sub-Department of Thai Binh Province is coping with job displacement of highly qualified employees, which affects the level of services and the province's socio-economic development goals.

If an individual has good psychological capital, that individual will have significant advantages in life and work. Any individual who has good characteristics of psychological capital can activate work motivation and increase work efficiency. In addition, the studies of Nguyen (2015), Vu and Nguyen (2018) on job satisfaction do not come from the perspective of psychological capital and empirical surveys in the state sector. Thus, the study aims to discover the relationship between psychological capital, organisational commitment, and job satisfaction of civil servants working at the Fisheries Sub-Department of Thai Binh Province. Based on the analysis results, the study suggests some policy implications to improve organisational commitment and job satisfaction of civil servants working at the Fisheries Sub-Department of Thai Binh Province in the future.

\section{Theoretical background and hypothesis}

\subsection{Theoretical background}

\subsubsection{Psychological capital}

Psychological capital is an important phenomenon of the new concepts of positive psychology and positive organisational behaviour (Ngwenya \& Pelser, 2020). Avey, Luthans, and Jensen (2009) define psychological capital exists in humans and a positive emotional state in personal development. Psychological capital has a positive impact on human nature supports individuals to achieve high job performance, and psychological capital is different from human capital (What you know?), social capital (Who you know?), financial capital (What do you have?). In terms of positive development, psychological capital answers the question of who you are and what you want (Luthans \& Youssef, 2004). Psychological capital is a state of positive emotional development of an individual, and it is a quadratic concept including four components: selfefficacy, hope, optimism, resiliency.

Self-efficacy is an awareness or belief regarding one's abilities to perform a task well in a work environment (Wood \& Wood, 1996). Self-efficacy related to five behaviours are (i) set higher goals; (ii) ready to overcome challenges to improve ability; (iii) full of energy and selfmotivation; (iv) strive to overcome difficulties to achieve good results; (v) try to persevere to overcome the challenge (Luthans, Avolio, Avey, \& Norman, 2007).

Hope is an individual's positive motivation based on the relationship between factors to achieve success, including thinking (intention towards a goal) and plans to achieve that goal 
(Snyder et al., 1991). Hope is the driving force that motivates individuals to try and strive to achieve their desires combined with methods to achieve goals even facing difficulties (Luthans \& Youssef, 2004) and different from wishful thinking (Luthans et al., 2007).

Seligman (1998) defines optimism as an individual's self-interpretation of situations positively occurring in everyday life. Optimism is an individual's state of expecting positive results (Scheier, Carver, \& Bridges, 2001). Luthans and Youssef (2004) argue that optimism in each individual is a belief and a positive attitude in life, knowing one's abilities and could get out of negative situations. Optimism is the most important component of psychological capital, and optimists believe that in the future, good things will come to them (Luthans et al., 2007).

Resiliency expresses through the persistence of each individual to overcome difficulties and quickly recover back to the original mental state or reach a higher level to achieve the desired results (Luthans et al., 2007). Luthans and Youssef (2004) illustrated that resilient people could change for the better through complexity.

\subsubsection{Organisational commitment}

Meyer and Hersovitch (2001) suggest that organisational commitment is a multidimensional structure and focuses on employees' attitudes towards the organisation. Allen and Meyer (1990, 1991) define organisational commitment as the emotional or affective attachment to the organisation, thereby realizing the individual's strong commitment, voluntary, participating, dreaming of being a member of the organisation. The theoretical model of the three components of organisational commitment was born to explain that organisational commitment creates by three distinct components expressing the psychological state of employees towards the organisation. Affective commitment is an emotional connection between an employee and the organisation, and the employee agrees with the targets and values of the organisation as well as the desire to stay in the organisation. Normative commitment is the employee's perception of responsibility and obligation to the organisation, and the employee has the perception to stay in the organisation. Continuance commitment is the comparison between the benefits and costs that an employee will lose if they decide to leave the organisation. Meyer, Allen, and Smith (1993) concluded that organisational commitment is an expression of a psychological state that links employees to the organisation and affects the decision to stay or intention to leave the organisation. Besides, employees with a high organisational commitment are more motivated to work and contribute more to the organisation than others (Meyer \& Allen, 1997). The concept and the three components of organisational commitment by Meyer and Allen are widely cited and used in the studies on organisational commitment (Benkhoff, 1997; D. K. Tran, 2006). Some studies focused on looking at overall organisational commitment, not delving into the components (Dang, 2018; Vu \& Nguyen, 2018).

\subsubsection{Job satisfaction}

Job satisfaction is an attitude variable, and it has attracted a lot of attention from researchers on organisational behaviour (Judge \& Kammeyer-Mueller, 2012). Locke (1976) defines job satisfaction as an employee's positive emotions through evaluating work or personal experience. Job satisfaction is the employee's general attitude towards the work process (Robbins, 2003). Luddy (2005) argues that job satisfaction is an employee's emotional or affective state towards various aspects of the work. Spector (1997) emphasized that job satisfaction is an employee's psychological state towards the job and different aspects of the job expressed through feelings of liking or disliking the current work. If employees feel that the job is suitable for their ability, they will have more job satisfaction. Employee job satisfaction is an important factor for organisational 
success (Spector, 1985). So, job satisfaction approaches in two different directions consist of overall job satisfaction and different aspects of job satisfaction (Friday \& Friday, 2003; D. K. Tran, 2005). Some studies suggest that the different aspects of job satisfaction will give managers more insight and make it easier to see which aspects bring job satisfaction and which aspects bring job dissatisfaction of employees (Deconinck \& Stilwell, 2004; Smith, Kendall, \& Hulin, 1969). However, some studies emphasize the importance of overall job satisfaction (Cronin, Brady, \& Hult, 2000), and overall job satisfaction is a better measure of job satisfaction than measuring different aspects of job satisfaction (Yu \& Dean, 2001).

\subsection{Hypothesis}

\subsubsection{The relationship between psychological capital and organisational commitment}

Aminikhah, Khaneghah, and Naghdian (2016) show that psychological capital has a direct impact on organisational commitment. Etebarian, Tavakoli, and Abzari (2012) examine the components of psychological capital and organisational commitment.The results show that psychological capital correlates with organisational commitment, with hope having a strong positive impact on organisational commitment. Resiliency has a negative impact on organisational commitment. Optimism and self-efficacy have a weak link with organisational commitment. A. T. H. Tran (2018) demonstrated four components of psychological capital that have a direct impact on organisational commitment, and she emphasized that hope has the most positive effect on organisational commitment. Hence, studies show that hope is an important factor in increasing engagement between organisations and employees. Self-efficacy will help employees set their own goals and appreciate the organisational targets, so employees will strive for work and desire to be committed to the organisation. Optimism will give employees positive feelings towards their current life and work. So, they will feel more committed to the organisation. Resilience brings employees the ability to face difficulties, and employees always have the organisational commitment to overcome any challenge at work. Therefore, the first hypothesis group proposed in this study is:

\section{H1.1: Self-efficacy has a positive effect on organisational commitment}

\section{H1.2: Hope has a positive effect on organisational commitment}

\section{H1.3: Optimism has a positive effect on organisational commitment}

\section{H1.4: Resilience has a positive effect on organisational commitment}

\subsubsection{The relationship between psychological capital and job satisfaction}

Peterson and Seligman (2003) show a direct relationship between psychological capital and job satisfaction. If employees have high hopes, they will have higher job satisfaction. Through empirical testing in different fields Abbas, Raja, Darr, and Bouckenooghe (2014), Luthans et al. (2007) conclude that four components of psychological capital have a positive impact on job satisfaction. In Vietnam, Ngo (2020) demonstrates that four components of psychological capital are positively correlated with job satisfaction. If employees have a high level of psychological capital will have positive beliefs about their future work and confidence in their abilities at work to face challenges at work (Newman, Ucbasaran, Zhu, \& Hirst, 2014). So, employees will strive to complete the work and increase job satisfaction. Hence, through elements of psychological capital starting from employees' positive emotions about the job and the organisation that they are working, employees will self-perceive the level of job satisfaction. Therefore, the second hypothesis group proposed in this study is: 
H2.1: Self-efficacy has a positive effect on job satisfaction

H2.2: Hope has a positive effect on job satisfaction

H2.3: Optimism has a positive effect on job satisfaction

H2.4: Resilience has a positive effect on job satisfaction

\subsubsection{The relationship between organisational commitment and job satisfaction}

There are many studies exploring the relationship between job satisfaction and organisational commitment. The current results are still inconsistent between the studies, and there are two opposing views. The first opinion shows that the studies emphasize job satisfaction as a prerequisite for organisational commitment (Fu, Deshpande, \& Zhao, 2011; Mowday, Porter, \& Steers, 1982). The second opinion shows that organisational commitment has a positive impact on job satisfaction. If employees are put in the correct position and fit for the organisation, they will feel organisational commitment before job satisfaction emerges (Vilela, González, \& Varela, 2008). According to Vandenberg and Lance (1992), Shahid and Azhar (2013) show that the more employees want to work for the organisation, the easier it is to create job satisfaction. In addition, Daneshfard and Ekvaniyan (2012) studied the relationship between job satisfaction and organisational commitment of employees working in the public sector. The results show that organisational commitment has a positive correlation with job satisfaction, in which affective commitment and normative commitment have the strongest impact on job satisfaction. Therefore, the third hypothesis proposed in this study is:

\section{H3: Organisational commitment has a positive effect on job satisfaction}

From the hypotheses, the authors propose the study framework by following:

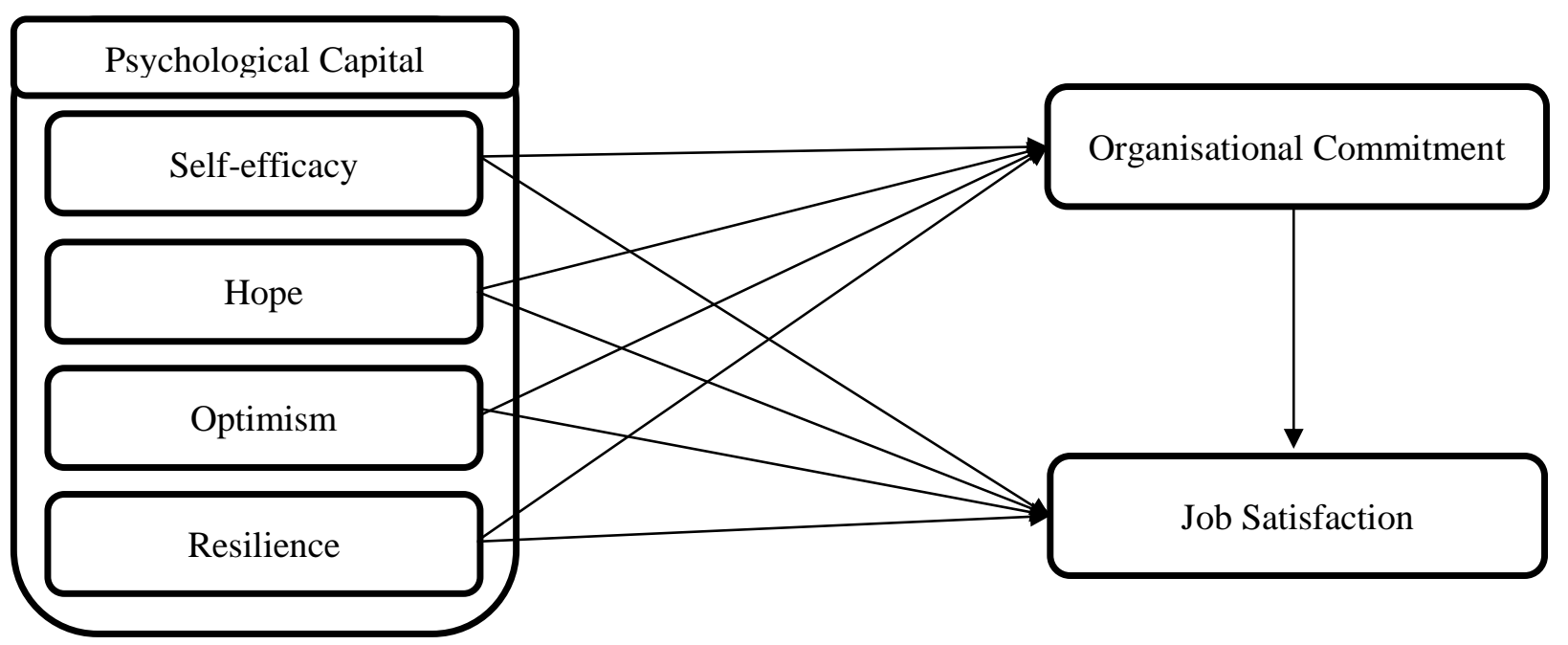

Source: The authors propose

Figure 1. Study framework

\section{Methodology}

\subsection{Scale design}

Preliminary scale is built based on the factors in the study framework and inherited from domestic and foreign studies. The Psychological Capital Questionnaire (PCQ) includes twentyfour observed variables of Luthans et al. (2007). In addition, the scale of organisational commitment of Dang (2018) includes four observed variables, and the scale of job satisfaction of Spector (1997) includes three observed variables. To be relevant to the field of study, the authors discussed with ten senior civil servants working at the Sub-Department of Fisheries in Thai Binh 
Province to carefully review the content related to factors add or remove inappropriate observed variables. Besides, in-depth interviews were conducted with five experts on human resources management to understand the relationships between factors affecting, adjust the study framework and solve problems arising during the discussion, including agree on opinions, carefully reviewing the variables in the scale, and clarifying the meaning of the survey. The results obtained everyone agreed that the factors in the proposed study framework are appropriate, and the psychological capital factor scale is kept unchanged. For the element of organisational commitment, 08/10 discussion participants and 04/05 experts think that it is necessary to adjust 03/04 observed variables because the meaning is not clear when researching in the public sector, easily confused with the factor of job satisfaction. For the factor of job satisfaction, 08/10 discussion participants think that it is necessary to add an observed variable to better the content. In addition, the authors adjusted words to be consistent for the public sector and the education level of survey participants.

\section{Table 1}

Measurement scale of factors in the study framework

\begin{tabular}{|c|c|c|}
\hline Abbr. & Variables & Source \\
\hline \multicolumn{3}{|c|}{ Self-efficacy } \\
\hline S1 & I am confident in finding solutions to long-standing work problems. & \multirow{6}{*}{$\begin{array}{l}\text { Luthans et al. } \\
\text { (2007), Research } \\
\text { by the authors } \\
\text { themselves. }\end{array}$} \\
\hline $\mathrm{S} 2$ & I am confident to present my work to the leader. & \\
\hline S3 & I am confident to discuss work with colleagues. & \\
\hline S4 & I am confident in setting work goals for myself. & \\
\hline S5 & $\begin{array}{l}\text { I am confident to discuss and contribute ideas to complete my work } \\
\text { tasks at the agency. }\end{array}$ & \\
\hline S6 & I am confident to exchange and contacting people. & \\
\hline \multicolumn{3}{|c|}{ Hope } \\
\hline $\mathrm{H} 1$ & I have many ways to deal with difficult situations at work. & \multirow{6}{*}{$\begin{array}{l}\text { Luthans et al. } \\
\text { (2007), Research } \\
\text { by the authors } \\
\text { themselves. }\end{array}$} \\
\hline $\mathrm{H} 2$ & I actively pursue work goals. & \\
\hline $\mathrm{H} 3$ & I think there are many ways to solve a problem. & \\
\hline $\mathrm{H} 4$ & I feel quite successful at work. & \\
\hline H5 & I have many ways to achieve your work goals. & \\
\hline H6 & I achieve my work goals. & \\
\hline \multicolumn{3}{|c|}{ Optimism } \\
\hline O1 & I always expect good things if work is not good. & \multirow{6}{*}{$\begin{array}{l}\text { Luthans et al. } \\
\text { (2007), Research } \\
\text { by the authors } \\
\text { themselves. }\end{array}$} \\
\hline $\mathrm{O} 2$ & I am always optimistic about my work. & \\
\hline $\mathrm{O} 3$ & I am optimistic about my future as it relates to my work. & \\
\hline O4 & I always think that mistakes at work are inevitable. & \\
\hline O5 & I love my job because it brings many things to contribute to society. & \\
\hline O6 & I am always optimistic about unlucky things happening at work. & \\
\hline \multicolumn{3}{|c|}{ Resilience } \\
\hline $\mathrm{R} 1$ & I can do many things at the same time. & \multirow{3}{*}{$\begin{array}{l}\text { Luthans et al. } \\
\text { (2007), Research } \\
\text { by the authors }\end{array}$} \\
\hline $\mathrm{R} 2$ & I have many ways to overcome all difficulties at work. & \\
\hline $\mathrm{R} 3$ & I can overcome the pressure at work. & \\
\hline
\end{tabular}




\begin{tabular}{|c|c|c|}
\hline Abbr. & Variables & Source \\
\hline R4 & I overcome difficulties thanks to my experiences. & \multirow[t]{3}{*}{ themselves. } \\
\hline R5 & I always give my best effort to overcome all difficulties at work. & \\
\hline R6 & I always complete all the assigned tasks. & \\
\hline \multicolumn{3}{|c|}{ Organisational Commitment } \\
\hline OC1 & $\begin{array}{l}\text { I am always enthusiastic and ideal for working at the government } \\
\text { agency. }\end{array}$ & \\
\hline $\mathrm{OC} 2$ & I accept all assignments to continue working at the agency. & \multirow{3}{*}{$\begin{array}{l}\text { Dang (2018), } \\
\text { Research by the } \\
\text { authors } \\
\text { themselves. }\end{array}$} \\
\hline OC3 & I am proud to be a member of the agency. & \\
\hline OC4 & I am willing to work long-term at the agency. & \\
\hline \multicolumn{3}{|c|}{ Job Satisfaction } \\
\hline JS1 & I love my current job. & \multirow{4}{*}{$\begin{array}{c}\text { Spector (1997), } \\
\text { Research by the } \\
\text { authors } \\
\text { themselves. }\end{array}$} \\
\hline JS2 & I have found a suitable job. & \\
\hline JS3 & I feel satisfied when working at the agency. & \\
\hline JS4 & I feel my work is very interesting. & \\
\hline
\end{tabular}

Source: Compiled by authors

\subsection{Sample size}

Hair, Sarstedt, Hopkins, and Kupplewieser (2014) said that the minimum sample size to use exploratory factor analysis is 50 , preferably 100 or more. The ratio of observations on an analytic variable of $5: 1$ or 10:1 will provide the minimum sample size of the study to ensure reliability. In this study, the authors use the 5:1 rule. The study has 32 observed variables, so the number of needed samples size is $32 * 5=160$.

The study uses a convenient sampling method for civil servants working at the SubDepartment of Fisheries in Thai Binh Province. To avoid the case of invalid answer sheets, the authors take the sample size of 275 respondents. After cleaning the data, the study collects 237 valid answer sheets with a return rate of $86.2 \%$. The survey period is from March $1^{\text {st }}$ to March $31^{\text {st }}$, 2021. Survey forms send directly email to civil servants working at the Sub-Department of Fisheries in Thai Binh Province.

\subsection{Data analysis}

The obtained data will be screened and analysed with SPSS version 26 and AMOS version 20 software. The study used analytical methods including descriptive statistics, reliability test of the scale by Cronbach's Alpha coefficient, Exploratory Factor Analysis (EFA), Confirmatory Factor Analysis (CFA). Structural Equation Modeling (SEM) uses to show the relationship between psychological, organisational commitment, and job satisfaction. To evaluate the reliability test of scale through two tools as Cronbach's Alpha and exploratory factor analysis. Cronbach's Alpha coefficient uses to eliminate "junk" items. The items with a total correlation coefficient less than 0.3 will not retain. The items will be selected if Cronbach's Alpha coefficient is more than 0.6 (Tabachnick \& Fidell, 2013). Exploratory factor analysis considers observed variables with transmission coefficients less than 0.5 and extracts two factors with a difference of less than 0.3 that will not retain. Eigenvalue (representing the variation explained by a factor) is greater than 1 , and the total variance extracted is more than 50\%. Besides, the KMO test and Bartlett test use to evaluate the reasonableness of the data (Hair, Anderson, Tatham, \& Black, 1998). For CFA and 
SEM analysis, the research model is suitable and good with the research data if $\mathrm{P}_{\text {value }}<0.05$; CMIN/df $\leq 2$; TLI và CFI $\geq 0.9 ;$ RMSEA $\leq 0.08$ (Hair, Black, Babin, $\&$ Anderson, 2010).

\section{Findings and discussion}

\subsection{Sample characteristics}

The results show that the prominent characteristics of civil servants working at the SubDepartment of Fisheries in Thai Binh Province participating in the survey are male, accounting for $57.9 \%$. The age group is from 30 to 50 years old, accounting for $81.9 \%$. The education level is mainly university, accounting for $87.9 \%$, and the seniority of work from five years to more than ten years, accounting for $94.1 \%$. The characteristics of the survey sample are consistent for the public sector in Vietnam. The employees in the public sector are almost men. According to the General Statistics Office (2020), the total number of employees working in the public sector is about four million people, with $70 \%$ men. They are between the ages of 30 and 50 years old, with high levels of education and many years of work experience. Table 2 summarizes the result of sample characteristics.

\section{Table 2}

Sample characteristics

\begin{tabular}{|c|c|c|}
\hline Characteristics & Number & Percent $(\%)$ \\
\hline \multicolumn{3}{|l|}{ Gender } \\
\hline Male & 137 & 57.9 \\
\hline Female & 100 & 42.1 \\
\hline \multicolumn{3}{|l|}{ Age } \\
\hline Under 30 years old & 5 & 2.1 \\
\hline From 30 to 50 years old & 194 & 81.9 \\
\hline More than 50 years old & 38 & 16.0 \\
\hline \multicolumn{3}{|l|}{ Education } \\
\hline Intermediate education and college & 8 & 3.3 \\
\hline University & 208 & 87.9 \\
\hline Post - Graduate & 21 & 8.8 \\
\hline \multicolumn{3}{|l|}{ Seniority } \\
\hline Under-five years & 5 & 2.1 \\
\hline From five years to 15 years & 223 & 94.1 \\
\hline More than 15 years & 9 & 3.8 \\
\hline \multicolumn{3}{|l|}{ Department } \\
\hline Administrative & 8 & 3.4 \\
\hline Aquaculture & 12 & 5.1 \\
\hline Exploitation and development of aquatic resources & 15 & 6.3 \\
\hline Inspection, legal & 7 & 3.0 \\
\hline Other units & 195 & 82.2 \\
\hline
\end{tabular}

Source: Authors' analysis 


\subsection{Reliability test of scale}

The results show that the lowest Cronbach's Alpha coefficient is 0.767 , and the highest is 0.887. Compared with standard 0.6, all observed items of the scale are satisfactory. Corrected itemtotal correlation greater than 0.3. Cronbach's alpha if items deleted of all 32 observed items is smaller than Cronbach's Alpha coefficient, so no items are excluded. All scales achieve two reliability and discriminant validity. Hence, the scale is good and meets the reliable requirement for exploratory factor analysis.

\subsection{Exploratory Factor Analysis (EFA)}

The study uses the Principal Axis Factoring extraction method along with Promax rotation. The study analyses the overall scale includes all observed items of psychological capital, job satisfaction, and organisational commitment. The study obtained results with the coefficient KMO $=0.886$; Bartlett Test is statistically significant with Sig. $=0.000(<0.05)$, and six factors were extracted with Eigenvalue $=1.375$; Sums of Squared Loadings $=79.253 \%$ (greater than 50\%). Six factors explained $79.253 \%$ of the variability of the data. Table 3 summarizes the results of the reliability test of scale and exploratory factor analysis.

Table 3

The results of the reliability test of scale and exploratory factor analysis

\begin{tabular}{|c|c|c|c|c|c|c|}
\hline \multirow{2}{*}{$\begin{array}{c}\text { Observed } \\
\text { items }\end{array}$} & \multicolumn{6}{|c|}{ Component } \\
\hline & 1 & 2 & 3 & 4 & 5 & 6 \\
\hline \multicolumn{7}{|c|}{ Self-efficacy: Cronbach's Alpha $=0.833$} \\
\hline S4 & 0.898 & & & & & \\
\hline S1 & 0.887 & & & & & \\
\hline S6 & 0.883 & & & & & \\
\hline S5 & 0.874 & & & & & \\
\hline $\mathrm{S} 2$ & 0.862 & & & & & \\
\hline S3 & 0.789 & & & & & \\
\hline \multicolumn{7}{|c|}{ Resilience: Cronbach's Alpha $=0.767$} \\
\hline R3 & & 0.892 & & & & \\
\hline R5 & & 0.888 & & & & \\
\hline R1 & & 0.872 & & & & \\
\hline $\mathrm{R} 2$ & & 0.868 & & & & \\
\hline R6 & & 0.854 & & & & \\
\hline $\mathrm{R} 4$ & & 0.832 & & & & \\
\hline \multicolumn{7}{|c|}{ Hope: Cronbach's Alpha $=0.887$} \\
\hline $\mathrm{H} 1$ & & & 0.879 & & & \\
\hline $\mathrm{H} 2$ & & & 0.860 & & & \\
\hline $\mathrm{H} 3$ & & & 0.851 & & & \\
\hline $\mathrm{H} 4$ & & & 0.846 & & & \\
\hline H5 & & & 0.839 & & & \\
\hline H6 & & & 0.788 & & & \\
\hline \multicolumn{7}{|c|}{ Organisational Commitment: Cronbach's Alpha $=0.799$} \\
\hline OC2 & & & & 0.899 & & \\
\hline
\end{tabular}


Nguyen D. Nam, Uong T. N. Lan. HCMCOUJS-EConomics and Business Administration, 12(1), 148-164 157

\begin{tabular}{|c|c|c|c|c|c|c|}
\hline \multirow{2}{*}{$\begin{array}{c}\text { Observed } \\
\text { items }\end{array}$} & \multicolumn{5}{|c|}{ Component } \\
\hline OC1 & & 2 & 3 & 4 & 5 & 6 \\
\hline OC3 & & & 0.880 & & \\
\hline OC4 & & & 0.878 & & \\
\hline Optimism: Cronbach's Alpha $=0.875$ & & 0.861 & & \\
\hline O5 & & & & 0.853 & \\
\hline O1 & & & & 0.848 & \\
\hline O3 & & & & 0.836 & \\
\hline O2 & & & & 0.822 & \\
\hline O6 & & & & 0.815 & \\
\hline O4 & & & & 0.798 & \\
\hline Job Satisfaction: Cronbach's Alpha $=0.821$ & & & & \\
\hline JS1 & & & & & & 0.885 \\
\hline JS4 & & & & & & 0.856 \\
\hline JS2 & & & & & & 0.811 \\
\hline JS3 & & & & & & \\
\hline
\end{tabular}

Source: Authors' analysis

\subsection{Confirmatory Factor Analysis (CFA)}

The results of CFA of the overall model scale show that the weights of the observed variables are all standard $(\geq 0.5)$. Hence, the scales reach convergent validity. The results show that the model has 568 degrees of freedom, the test value CMIN (Chi-square) $=521.135$ with Pvalue $=0.000 ;$ CMIN/df (Chi-square/pdf $)=2.543<3$ and the Goodness of Fit index $=0.901$; Tucker-Lewis index $=0.917$; Comparative Fit index $=0.929$ greater than 0.9 ; the root mean square error of approximation $=0.030$ less than 0.08 . So, the research model is consistent with the research data. Figure 2 summarizes the results of the confirmatory factor analysis.

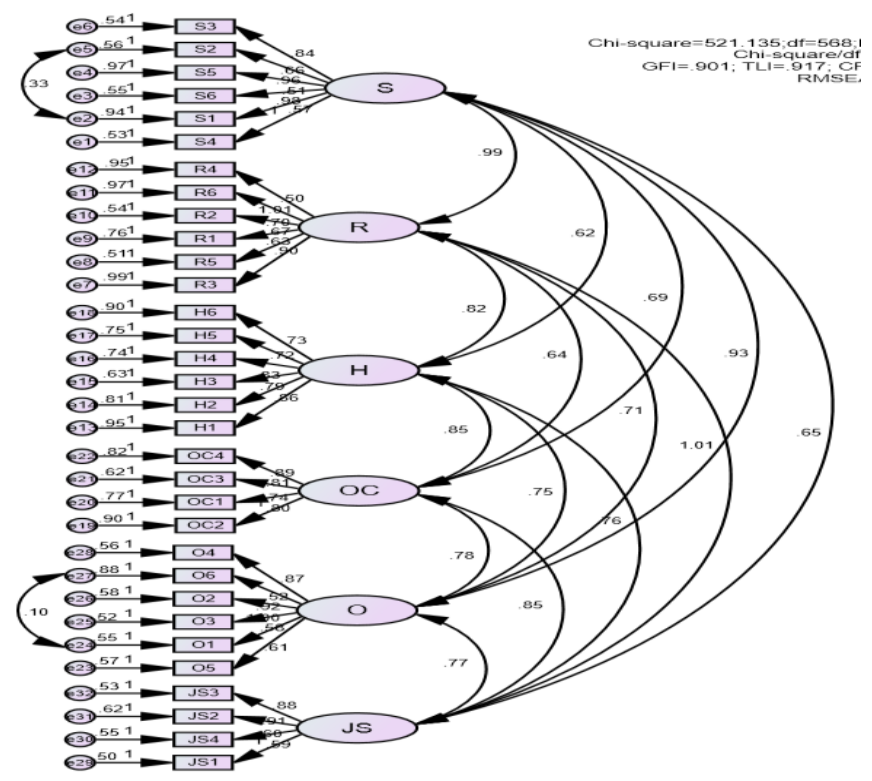

Figure 2. The results of the confirmatory factor analysis of the overall model scale Source: Authors' analysis 


\subsection{Structural Equation Modeling (SEM)}

Based on the outcomes of the confirmatory factor analysis of the overall model scale, the results of the structural equation modeling are consistent with the research data. That is shown by the CMIN/df (Chi-square/pdf) $=2.874<3$ and the Goodness of Fit index $=0.905$, Tucker-Lewis index $=0.922$, Comparative Fit index $=0.933$ greater than 0.9 ; the root mean square error of approximation $=0.035$ is less than 0.08 .

At the same time, based on the analysis results, the $\mathrm{P}_{\text {value }}$ of the impact relationships between the factors is less than 0.05 . Hence, the relationship between psychological capital, organisational commitment, and job satisfaction is statistically significant in the Structural Equation Modeling (SEM). Table 4 summarizes the model results.

\section{Table 4}

The results of the reliability test of scale and exploratory factor analysis

\begin{tabular}{|l|l|c|c|c|c|}
\hline \multicolumn{2}{|c|}{ Correlation } & Estimate & S.E & C.R & P \\
\hline Organisational Commitment & $\longleftarrow$ Self-efficacy & 0.387 & 0.074 & 3.725 & 0.000 \\
\hline Organisational Commitment & $\longleftarrow$ Resilience & 0.374 & 0.062 & 3.651 & 0.000 \\
\hline Organisational Commitment & $\longleftarrow$ Hope & 0.476 & 0.069 & 0.704 & 0.000 \\
\hline Organisational Commitment & $\longleftarrow$ Optimism & 0.489 & 0.082 & 2.261 & 0.000 \\
\hline Job Satisfaction & $\longleftarrow$ Self-efficacy & 0.385 & 0.188 & 2.171 & 0.000 \\
\hline Job Satisfaction & $\longleftarrow$ Resilience & 0.362 & 0.093 & 3.394 & 0.000 \\
\hline Job Satisfaction & $\longleftarrow$ Hope & 0.483 & 0.197 & 2.363 & 0.000 \\
\hline Job Satisfaction & $\longleftarrow$ Optimism & 0.477 & 0.194 & 2.953 & 0.000 \\
\hline Job Satisfaction & $\longleftarrow$ Organisational & 0.501 & 0.078 & 1.918 & 0.000 \\
& Commitment & & & & \\
\hline
\end{tabular}

Source: Authors' analysis

The coefficients of direct effect, indirect effect, and synthetic effect are use to evaluate the impact of factors on job satisfaction. The results show that the biggest impact is organisational commitment $(\lambda=0.501)$, followed by hope $(\lambda=0.483)$, optimism $(\lambda=0.477)$, self-efficacy $(\lambda=$ $0.385)$, and the least impact factor is resiliency $(\lambda=0.362)$. Table 5 summarizes the results of direct and indirect impact factors on job satisfaction.

\section{Table 5}

Impact of factors on job satisfaction

\begin{tabular}{|c|c|c|c|c|c|c|}
\hline Variables & Effects & $\mathbf{S}$ & $\mathbf{H}$ & $\mathbf{O}$ & $\mathbf{R}$ & OC \\
\hline \multirow{3}{*}{ OC } & Direct & 0.387 & 0.476 & 0.489 & 0.374 & 0.000 \\
\cline { 2 - 7 } & Indirect & 0.000 & 0.000 & 0.000 & 0.000 & 0.000 \\
\cline { 2 - 7 } & Synthetic & 0.387 & 0.476 & 0.489 & 0.374 & 0.000 \\
\hline \multirow{3}{*}{ JS } & Direct & 0.000 & 0.000 & 0.000 & 0.000 & 0.501 \\
\cline { 2 - 7 } & Indirect & 0.385 & 0.483 & 0.477 & 0.362 & 0.000 \\
\cline { 2 - 7 } & Synthetic & 0.385 & 0.483 & 0.477 & 0.362 & 0.501 \\
\hline
\end{tabular}


The results show that psychological capital has a positive effect on organisational commitment and job satisfaction of civil servants working at the Sub-Department of Fisheries in Thai Binh Province. Four factors of psychological capital, including self-efficacy, resilience, hope, and optimism have a positive effect on organisational commitment and job satisfaction. The results are similar to the studies of Aminikhah et al. (2016), Etebarian et al. (2012), A. T. H. Tran (2018), Peterson and Seligman (2003), Abbas et al. (2014), Luthans et al. (2007). Optimism has the strongest impact on organisational commitment and job satisfaction. Civil servants with optimism and flexibility will help them promote efficiency in their working process. Optimism will help civil servants continue working hard if they face difficulties and calmly accept reality and develop a next work plan without sadness or despair. The barriers always appear in the working process of officials and civil servants, forcing them to face and overcome. Along with optimism, hope will help civil servants to be active in their work and create the right way to do their jobs successfully. In addition, self-efficacy has a significant impact on organisational commitment and job satisfaction of civil servants working at the Sub-Department of Fisheries in Thai Binh Province. Self-efficacy is one's ability brings resilience at work.

The result also shows that organisational commitment has a positive effect on job satisfaction of civil servants working at the Sub-Department of Fisheries in Thai Binh Province. The result is similar to the studies of Vilela et al. (2008), Vandenberg and Lance (1992), Shahid and Azhar (2013).

Thus, five direct and indirect impact factors on job satisfaction include self-efficacy, hope, optimism, resiliency, and organisational commitment. That is the difference from the studies of Nguyen (2015), Vu and Nguyen (2018). Because the previous studies did not measure organisational commitment and job satisfaction of employees in the public sector based on psychological capital.

\section{Conclusion and policy implication}

In this study, the relationship between psychological capital, organisational commitment, and job satisfaction analysis through the data set obtained by the direct survey method of civil servants working at the Sub-Department of Fisheries in Thai Binh Province. Confirmatory factor analysis, structural equation modeling analyses were performed to determine the relationship between the constructs in the research model. The analysis results show that a direct impact of psychological capital on organisational commitment and psychological capital has an indirect impact on job satisfaction. Besides, organisational commitment has a positive effect on the job satisfaction of civil servants working at the Sub-Department of Fisheries in Thai Binh Province.

Based on the obtained results, the study provides some policy implications to help the SubDepartment of Fisheries in Thai Binh Province improve organisational commitment and job satisfaction of civil servants:

Firstly, leaders of the Sub-Department should try to accurately assess the psychological capital of civil servants through the regular implementation of multiple-choice tests on employees' psychological capital to increase organisational commitment and job satisfaction.

Second, periodically evaluate and organise short-term psychological training courses for employees. In addition, it is necessary to develop psychological counseling sessions with psychologists to help civil servants deal with psychological problems to reduce the negative impact on organisational commitment and job satisfaction. Leaders of the Sub-department need to pay attention to the training of civil servants to have positive thoughts, reduce stress, and lower the morale of civil servants. 
Third, the Sub-Department should create a friendly working environment with many cohesive activities and development programs. For example, the Sub-Department could organise parties assign new roles for civil servants. And the Sub-Department should conduct programs to promote the ideas of civil servants. Thereby creating an organisational commitment of civil servants and increasing job satisfaction of civil servants.

\section{Limitations and future research}

There are still some limitations of this study, including (i) the small limited sample size. This study was conducted only at the Sub-Department of Fisheries in Thai Binh Province; (ii) the study tested the hypothesis by collecting data from civil servants working at the Sub-Department of Fisheries in Thai Binh Province with a convenient sampling method.

Therefore, some implications for future research could include: (i) increase the sample size or extend the scope; (ii) future studies should consider the impact of psychological capital on organisational commitment and job satisfaction using the probability sampling method to increase the generalizability of the study.

\section{References}

Abbas, M., Raja, U., Darr, W., \& Bouckenooghe, D. (2014). Combined effects of perceived politics and psychological capital on job satisfaction, turnover intentions, and performance. Journal of Management, 40(7), 1813-1830.

Allen, N. J., \& Meyer, J. P. (1990). The measurement and antecedents of affective, continuance and normative commitment to the organisation. Journal of Occupational Psychology, 63(1), $1-18$.

Allen, N. J., \& Meyer, J. P. (1991). A three-component conceptualization of organisational commitment. Human Resource Management Review, 1(1), 61-89.

Al-Mashaan, O. S. (2003). Associations among job satisfaction, optimism, pessimism, and psychosomatic symptoms for employees in the government sector in Kuwait. Psychological Reports, 93(1), 17-25.

Aminikhah, H., Khaneghah, T. M., \& Naghdian, M. (2016). The relationship of psycological capital and job satisfaction with organisational commitment. International Journal of Information, Business and Management, 8(1), 153-171.

Avey, J. B., Luthans, F., \& Jensen, S. M. (2009). Psychological capital: A positive resource for combating employee stress and turnover. Human Resource Management, 48(5), 677-693.

Badran, M. A., \& Youssef-Morgan, C. M. (2015). Psychological capital and job satisfaction in Egypt. Journal of Managerial Psychology, 30(3), 354-370.

Benkhoff, B. (1997). Ignoring commitment is costly: New approaches established the missing link between commitment and performance. Human Relations, 50(6), 701-727.

Carver, C. S., Lehman, J. M., \& Antoni, M. H. (2003). Dispositional pessimism predicts illnessrelated disruption of social and recreational activities amongbreast cancer patients. Journal of Personality and Social Psychology, 84(4), 813-821.

Cronin, J. J., Brady, M. K., \& Hult, G. T. (2000). Assessing the effects of quality, value, and customer satisfaction on consumer behavioural intentions in service environments. Journal of Retailing, 76(2), 193-218. 
Daneshfard, C., \& Ekvaniyan, K. E. (2012). Organisational commitment and job satisfaction in Islamic Azad University. Interdisciplinary Journal of Contemporary Research in Business, 3(9), 168-181.

Dang, T. S. (2018). Factors affecting organisational commitment of civil servants at the People's Committee of District 10, Ho Chi Minh City (Master's thesis). Ho Chi Minh City University of Technology, Ho Chi Minh City, Vietnam.

DeConinck, J. B., \& Stilwell, C. D. (2004). Incorporating organisational justice, role states, pay satisfaction and supervisor satisfaction in a model of turnover intentions. Journal of Business Research, 57(3), 225-231.

Etebarian, A., Tavakoli, S., \& Abzari, M. (2012). The relationship between psychological capital and organisational commitment. African Journal of Business Management, 6(14), 50575060 .

Firth, L. A., Mellor, D. J., Moore, K. A., \& Loquet, C. (2004). How can managers reduce employee intention to quit? Journal of Managerial Psychology, 19(2), 170-187.

Fisheries Sub-Department of Thai Binh Province. (2020). Summary report 2020. Retrieved May 10, 2021, from https://sonnptnt.thaibinh.gov.vn/tin-tuc-su-kien/thong-tin-chuyennganh/thuy-san

Friday, S. S., \& Friday, E. (2003). Racioethnic perceptions of job characteristics and job satisfaction. Journal of Management Development, 22(5), 426-442.

Fu, W., Deshpande, S. P., \& Zhao, X. (2011). The impact of ethical behaviour and facets of job satisfaction on organisational commitment of chinese employees. Journal of Business Ethics, 104(4), 537-543.

General Statistics Office. (2020). Total number of employees working in the state economic sector. Retrieved May 10, 2021, from https://www.gso.gov.vn/px-web-2/?pxid=V0235\&theme= D\%C3\%A2n\%20s\%E1\%BB\%91\%20v\%C3\%A0\%201ao\%20\%C4\%91\%E1\%BB\%99ng

Hair, J. F. J., Anderson, R. E., \& Tatham, R. L. (1998). Multivariate data analysis with readings. Englewood Cliffs, NJ: Prentice-Hall.

Hair, J. F. J., Anderson, R. E., Tatham, R. L., \& Black, W. C. (1998). Multivariate data analysis (5th ed.). Upper Saddle River, NJ: Prentice Hall.

Hair, J. F. J., Black, W. C., Babin, B. J., \& Anderson, R. E. (2010). Multivariate data analysis (7th ed.). Upper Saddle River, NJ: Prentice Hall.

Hair, J., Sarstedt, M., Hopkins, L., \& Kupplewieser, V. (2014). Partial Least Squares Structural Equation Modeling (PLS-SEM): An emerging tool for business research. European Business Review, 26(2), 106-121.

John, F. R. (2021). Influence of psychological capital on employee engagement and explored the mediating role of organisational commitment. European Journal of Molecular \& Clinical Medicine, 8(3), 3222-3231.

Judge, T. A., \& Kammeyer-Mueller, J. D. (2012). Job attitudes. Annual Review of Psychology, 63(1), 341-367.

Karatepe, O. M., \& Karadas, G. (2015). Do psychological capital and work engagement foster frontline employees' satisfaction? International Journal of Contemporary Hospitality Management, 27(6), 1254-1278. 
Kreitner, R., Kinicki, A., \& Buelens, M. (2007). Organisational behaviour. New York, NY: McGraw Hill.

Kwok, S., Cheng, L., \& Wong, D. F. K. (2015). Family emotional support, positive psychological capital and job satisfaction among chinese white-collar workers. Journal of Happiness Studies, 16(3), 1-20.

Lerouge, C., Nelson, A., \& Blanton, J. E. (2006). The impact of role stress fit and self-esteem on the job attitudes of IT professionals. Information \& Management, 43(8), 928-938.

Locke, E. A. (1976). The nature and causes of job satisfaction. In M. D. Dunnette (Eds.), Handbook of industrial and organisational psychology (pp. 1297-1349). Retrieved May 20, 2021, from https://scholar.google.com/scholar_lookup?title=The\%20nature\%20and\%20causes\%20of \%20job\%20satisfaction\&pages=1297-1349\&publication_year=1976\&author=Locke\%2CE.\%20A

Luddy, N. (2005). Job satisfaction amongst employees at a public health institution in the Western Cape (Master's thesis). University of the Western Cape, Bellville, Cape Town, South Africa.

Luthans, F., \& Avolio, B. J. (2003). Authentic leadership: A positive developmental approach. In K. S. Cameron, J. E. Dutton \& R. E. Quinn (Eds.), Positive organisational scholarship (pp. 241-261). San Francisco, CA: Barrett-Koehler.

Luthans, F., \& Youssef, C. M. (2004). Human, social, and now positive psychological capital management: Investing in people for competitive advantage. Organisational Dynamics, $33(2), 143-160$.

Luthans, F., Avey, J. B., Avolio, B. J., Norman, S., \& Combs, G. (2006). Psychological capital development: Toward a micro-intervention. Journal of Organisational Behaviour, 27, 387-393.

Luthans, F., Avolio, B., Avey, J., \& Norman, S. (2007). Psychological capital: Measurement and relationship with performance and satisfaction. Personnel Psychology, 60(3), 541-572.

Malik, A. (2013). Efficacy, hope, optimism and resilience at workplace-positive organisational behaviour. International Journal of Scientific and Research Publications, 3(10), 1-4.

Matos, P. S., Griffin, M. T. Q., Fitzpatrick, J., \& Neushotz, L. A. (2010). An exploratory study of resilience and job satisfaction among psychiatric nurses working in inpatient units. International Journal of Mental Health Nursing, 19(5), 307-312.

Meng, Y., Qi, S. H., \& Li, L. (2011). A study on the impact of hotel leaders' psychological capital on employee engagement. Paper presented at the International Conference on Services Systems and Services Management, IEEE Publisher, Tianjin, China.

Meyer, J. P., \& Allen, N. J. (1997). Commitment in the workplace: Theory, research, and application. Thousand Oaks, CA: SAGE Publications Inc.

Meyer, J. P., \& Herscovitch, L. (2001). Commitment in the workplace: Toward a general model. Human Resource Management Review, 11(3), 299-326.

Meyer, J., Allen, N., \& Smith, C. (1993). Commitment to organisations and occupations: Extension and test of a three-component conceptualization. Journal of Applied Psychology, 78(4), 538-551.

Mirkamali, S. M., \& Narenji, T. F. (2011). A study on the Quality of Work Life (QWL) among faculty members of University of Tehran (UT) and Sharif university of Technology (SUT). Procedia - Social and Behavioural Sciences, 29(1), 179-187. 
Mowday, R., Porter, L., \& Steers, R. (1982). Employee-organisation linkages: The psychology of commitment, absenteeism, and turnover. Cambridge, MA: Academic Press.

Nasab, S. H., Asgari, A., \& Ayati, M. (2015). The relation between academic optimism and motivation of academic advancement with respect of mediating role of academic efficacy of the second grade students. International Journal of Social Science and Education, 5(4), 707-722.

Newman, A., Ucbasaran, D., Zhu F., \& Hirst, G. (2014). Psychological capital: A review and synthesis. Journal of Organisational Behaviour, 35(1), 120-138.

Ngo, T. T. (2020). Psychological capital, work attitude and work performance of employees (Doctoral dissertation). Ho Chi Minh City Open University, Ho Chi Minh City, Vietnam.

Nguyen, T. H. N. (2015). Effect of job satisfaction on organisational commitment of pharmacists in foreign pharmaceutical companies in Ho Chi Minh City (Master's thesis). University of Economics Ho Chi Minh City, Ho Chi Minh City, Vietnam.

Ngwenya, B., \& Pelser, T. (2020). Impact of psychological capital on employee engagement-job satisfaction and employee performance. SA Journal of Industrial Psychology, 46(4), 1-12.

Peterson, C. M., \& Seligman, M. E. P. (2003). Positive organisational studies: Lessons from positive psychology. In K. S. Cameron, J. E. Dutton \& R. E. Quinn (Eds.), Positive organisational scholarship (pp. 14-27). San Francisco, CA: Berrett-Koehler.

Price, J. L. (1997). Handbook of organisational measurement. International Journal of Manpower, 18(4/5/6), 305-558.

Robbins, S. P. (2003). Organisational behaviour (10th ed.). Upper Saddle River, NJ: Prentice Hall.

Scheier, M. F., Carver, C. S., \& Bridges, M. W. (2001). Optimism, pessimism, and psychological well-being. In E. C. Chang (Ed.), Optimism and pessimism: Implications for theory, research, and practice (pp. 189-216). Washington, D.C.: American Psychological Association.

Seligman M. E. P. (1998). Learned optimism. New York, NY: Random House Inc.

Shahid, A., \& Azhar, S. M. (2013). Gaining employee commitment: Linking to organisational effectiveness. Journal of Management Research, 5(1), 250-268.

Siu, O. L., Spector, P. E., Cooper, C. L., \& Lu, C. Q. (2005). Work stress, self efficacy, Chinese work values, and work well-being in Hong Kong and Beijing. International Journal of Stress Management, 12(3), 274-288.

Smith, P. C., Kendall, L. M., \& Hulin, C. L. (1969). Measurement of satisfaction in work and retirement. Chicago, IL: Rand McNally.

Snyder, C. R., Harris, C., Anderson, J. R., Holleran, S. A., Irving, L. M., Sigmon, S. T., ... Harney, P. (1991). The will and the ways: Development and validation of an individual-differences measure of hope. Journal of Personality and Social Psychology, 60(4), 570-585.

Spector, P. E. (1985). Measurement of human service staff satisfaction: Development of the job satisfaction survey. American Journal of Community Psychology, 13(6), 693-713.

Spector, P. E. (1997). Job satisfaction: Application, assessment, causes, and consequences. Thousand Oaks, CA: SAGE Publication Inc. 
Spreitzer, G. M., \& Porath, C. L. (2012). Creating sustainable performance. Harvard Business Review, 90(1/2), 92-99.

Tabachnick, B. G., \& Fidell, L. S. (2013). Using multivariate statistics (6th ed.). Boston, MA: Pearson.

Tran, A. T. H. (2018). Testing the mediating role of work engagement in the relationship between psychological capital and organisational commitment in enterprises in Ho Chi Minh City (Master's thesis). University of Economics Ho Chi Minh City, Ho Chi Minh City, Vietnam.

Tran, D. K. (2005). Job satisfaction in a Vietnamese context. Journal of Economics Development, 181(11), 1-9.

Tran, D. K. (2006). The scale of consciousness of organisational commitment. Journal of Economics Development, 184(2), 50-52.

Vandenberg, R. J., \& Lance, C. (1992). Examining the causal order of job satisfaction and organisational commitment. Journal of Management, 18(1), 153-167.

Vilela, B., González, J. A., \& Varela, F. P. (2008). Person-organisation fit, OCB and performance appraisal: Evidence from matched supervisor-salesperson data set in a Spanish context. Industrial Marketing Management, 37(8), 1005-1079.

Vu, H. V., \& Nguyen, T. V. (2018). The correlation among job satisfaction, organisational commitment and turnover intention - A case of technical staff in it infrastructure services sector. Ho Chi Minh City Open University Journal of Science, 13(2), 188-204.

Wood, S., \& Wood, E. (1996). The world of psychology (2nd ed.). Boston, MA: Allyn and Bacon.

Youssef, C. M., \& Luthans, F. (2007). Positive organisational behaviour in the workplace: The impact of hope, optimism, and resilience. Journal of Management, 33(5), 774-800.

Yu, Y., \& Dean, A. (2001). The contribution of emotional satisfaction to consumer loyalty. International Journal of Service Industry Management, 12(3), 234-250. 